\title{
Flask sealing on in vitro seed germination and morphogenesis of two types of ornamental pepper explants
}

\author{
Diego Silva Batista ${ }^{1}$ Leonardo Lucas Carnevalli Dias ${ }^{2}$ Mailson Monteiro do Rêgo ${ }^{3}$ \\ Cleber Witt Saldanha ${ }^{4}$ Wagner Campos Otoni $^{1^{*}}$
}

\author{
${ }^{1}$ Laboratório de Cultura de Tecidos Vegetais, Universidade Federal de Viçosa (UFV), 36570-000, Viçosa, MG, Brasil. E-mail: wcotoni@gmail.com. \\ ${ }^{*}$ Corresponding author. \\ ${ }^{2}$ Universidade Federal de São João del Rei (UFSJ), Sete Lagoas, MG, Brasil. \\ ${ }^{3}$ Universidade Federal da Paraíba (UFPB), Areia, PB, Brasil. \\ ${ }^{4}$ Fundação Estadual de Pesquisa Agropecuária (FEPAGRO), Santa Maria, RS, Brasil.
}

\begin{abstract}
The influence of flask sealing and explant source on the in vitro morphogenesis of pepper, were evaluated in Capsicum annuum. Seeds were sterilized and inoculated in Murashige and Skoog media supplemented with vitamins, myo-inositol, sucrose, and agar. Gas exchange was evaluated in the germination stage by comparing 3 flask-sealing systems: rigid polypropylene lids (PLs) without vents, PLs with 1 vent, and $P L s$ with 2 vents covered with membranes. In the regeneration stage, cotyledon and hypocotyl segments were transferred to the organogenesisinducing media, being the different sealing types also tested in a factorial scheme. Photosynthetic pigments, morphological and hystological analyses were conducted for each treatment. Plants maintained in glass flasks capped with vented lids showed more vigorous growth and differentiated anatomical structures. These treatments resulted in taller plants, higher numbers and more expanded leaves, higher fresh and dry weights, and an increase in photosynthetic pigments. Cultivation of C. annuum in flasks with reduced gas exchange was more effective on callus induction. During the regeneration stage, hypocotyls were more effective than cotyledons. Sealing type influenced the morphogenic responses of pepper, demonstrating that an increase in gas exchange has a positive effect on biomass production and acclimatization of the plantlets.
\end{abstract} Key words: micropropagation, gas exchange, ornamental plant, Capsicum annuum.

Tipo de vedação na germinação e na morfogênese in vitro de dois tipos de explante de pimenteira ornamental

RESUMO: Objetivando avaliar a influência de trocas gasosas e da fonte de explante na morfogênese in vitro de pimenteira ornamental, sementes de Capsicum annuum foram desinfestadas e inoculadas em meio de Murashige e Skoog suplementado com vitaminas, mio-inositol, sacarose e ágar. O efeito das trocas gasosas foi avaliado na fase de germinação, utilizando três tipos de vedações nos frascos: tampas de polipropileno rigido (TPR) sem membrana (controle), TPR com um orificio (10mm de diametro) coberto com membrana e TPR com dois orificios cobertos com membranas permeáveis à gases. Na fase de regeneração, segmentos de hipocótilo e cotilédones foram transferidos para o meio de indução de organogênese e os diferentes tipos de vedação foram novamente testados em esquema fatorial. Análises anatômicas de pigmentos fotossintéticos e de características morfológicas foram realizadas. Plântulas cultivadas em frascos com tampas com membranas apresentaram estruturas anatomicas diferenciadas e mais vigorosas. Esses tratamentos resultaram em plântulas maiores, com folhas mais expandidas, maior número de folhas, maior massa fresca e seca e maior quantidade de pigmentos fotossintéticos. O cultivo de C. annuum em frascos com menores trocas gasosas foi mais eficaz na indução de calos. Durante o estágio de regeneração, hipocótilos foram mais eficazes do que cotilédones. O tipo de vedação influenciou nas respostas morfogênicas em pimenteira, demonstrando que o aumento nas trocas gasosas tem um efeito positivo sobre a produção de biomassa e aclimatização das plântulas.

Palavras-chave: micropropagação, trocas gasosas, planta ornamental, Capsicum annuum.

\section{INTRODUCTION}

Acclimatization is a key process in the production of healthy plantlets. However, this process is complicated due differences in variables, such as relative humidity $(\mathrm{RH})$, temperature, ventilation, and nutrient concentrations between the ex vitro environment and the in vitro environment (CHA-UM et al., 2010). Low $\mathrm{CO}_{2}$ concentrations and ethylene accumulation in closed flasks are factors that can directly interfere in in vitro photosynthetic rates of plants and; thus, in their multiplication rate and survival during acclimatization (ARAGÓN et al., 2010). Furthermore, RH inside the flasks can cause anatomical anomalies that generally reduce the survival rate during acclimatization (HAZARIKA, 2006).

Lids that allow higher gas exchange through membranes were used to improve ventilation inside culture flasks, reducing $\mathrm{RH}$ and thereby increasing transpiration and effective water and nutrient 
absorption in plants (KOZAI, 2010; XIAO et al., 2011). MilliSeal ${ }^{\circledR}$ membranes have been successfully used to improve gas exchange in the culture flask in the propagation of many species, including Pfaffia glomerata (IAREMA et al., 2012; SALDANHA et al., 2013, 2014; CORRÊA et al., 2015), Azadirachta indica (RODRIGUES et al., 2011), Alha gigraecorum (ZOBAYED et al., 2006), and Eucalyptus tereticornis (SHAVALLI KHAN et al., 2002).

Unlike other members of the Solanaceae family, which have morphogenesis easily reproduced protocols, chillies and peppers of the genus Capsicum are recalcitrant to in vitro culturing. Nevertheless, certain protocols for their micropropagation have been established (KOTHARI et al., 2010). SANTANABUZZY et al. (2005) reported a high sensitivity to ethylene in peppers and observed chlorosis and leaf abscission in leaf primordia development with quick loss of vigor. However, when these explants were kept in vessels that allowed higher gas exchange, regeneration and plantlet development proceeded normally. MOHAMED \& ALSADON (2011) evaluated the effect of gas exchange in the micropropagation of Capsicum annuum and observed that the type of flask used affects the appearance of morphogenic calli, organogenesis, and plantlet growth. GARRUÑA-HERNÁNDEZ et al. (2013) also reported that an increased $\mathrm{CO}_{2}$ concentration has a positive effect on pungency in Capsicum chinense Jacq. suggesting that at least part of the additional fixed $\mathrm{CO}_{2}$ could be directed to the capsaicinoids synthesis. This study aimed to evaluate the effect of flask sealing and explant type on the in vitro morphogenesis of ornamental pepper.

\section{MATERIALS AND METHODS}

Seeds of $\boldsymbol{C}$. annuum were obtained from the Vegetable Germplasm Stock at the Center for Agricultural Sciences, Universidade Federal da Paraíba (BAGH-CCA/UFPB), Brazil. They were disinfected under aseptic conditions by immersion into a $70 \%(\mathrm{v} / \mathrm{v})$ alcohol solution for 60 seconds, followed by immersion into a $5 \%(\mathrm{v} / \mathrm{v})$ commercial sodium hypochlorite solution (Super Globo ${ }^{\mathrm{TM}}$, Brazil) for 10 minutes and rinsed 4 times with deionized, autoclaved water. The seeds were transferred to $250-$ $\mathrm{mL}$ glass flasks containing $50 \mathrm{~mL}$ of Murashige and Skoog media (MURASHIGE \& SKOOG, 1962) with vitamins, $30 \mathrm{~g} \mathrm{~L}^{-1}$ of sucrose, $100 \mathrm{mg} \mathrm{L}^{-1}$ of myoinositol, and $8 \mathrm{~g} \mathrm{~L}^{-1}$ of granulated agar (Merck ${ }^{\mathrm{TM}}$, Germany). The $\mathrm{pH}$ was adjusted to $5.7 \pm 0.01$, and the media was autoclaved at $120^{\circ} \mathrm{C}$ and $1.1 \mathrm{kPa}$ for
20 minutes. Three types of flask-sealing systems were used: polypropylene lids (PLs) without membranes $\left[14 \mu \mathrm{L} \mathrm{L}^{-1} \mathrm{~s}^{-1} \mathrm{CO}_{2}\right.$ exchange rate (CER)], PLs with one $0.45-\mu \mathrm{m}$-pore-size membrane (MilliSeal ${ }^{\mathrm{TM}}$ AVS045 Air Vent) $\left(21 \mu \mathrm{L} \mathrm{L}^{-1} \mathrm{~s}^{-1}\right.$ CER), and PLs with 2 membranes $\left(25 \mu \mathrm{L} \mathrm{L}^{-1} \mathrm{~s}^{-1} \mathrm{CER}\right)$. Seeds were germinated in a growth-room environment with a light regime of $16 \mathrm{~h}$ and irradiance of $60 \mu \mathrm{mol} \mathrm{m}^{-2} \mathrm{~s}^{-1}$ using 2 fluorescent lamps (HO Sylvania $\mathrm{T} 12-110 \mathrm{~W}$ ) at $25 \pm 2^{\circ} \mathrm{C}$.

Ten-millimeter-long hypocotyl and cotyledon segments of in vitro germinated C. annuum plantlets were inoculated into a morphogenesis-inducing media enriched with the growth regulators 6-BA (6-Benzylaminopurine) $(22.2 \mu \mathrm{M})$ and IAA (Indole-3-acetic acid) $(5.71 \mu \mathrm{M})$. Subsequently, 5 explants were added to a $250-\mathrm{mL}$ glass flask using the same gas exchange levels that were used in the germination media.

Effects of each treatment were evaluated throughout the entire plantlet growth period by monitoring the following characteristics: germination (\%), fresh weight (g), hypocotyl length $(\mathrm{cm})$, leaf length $(\mathrm{mm})$, leaf width $(\mathrm{mm})$, and number of leaves per plantlet.

After 30 days of germination, chlorophyll $a$, chlorophyll $b$, and carotenoids were performed according to SANTOS et al. (2008), 6 leaf discs ( $7 \mathrm{~mm}$ in diameter) were removed from the third expanded leaf of the shoot apical meristem and incubated for $48 \mathrm{~h}$ in the dark in $5 \mathrm{~mL}$ of dimethyl sulfoxide solution (saturated with calcium carbonate). Absorbances were determined at 665,649 , and $480 \mathrm{~nm}$ and the equations used for calculations were based on the method described by WELLBURN (1994).

For histochemical analyses, samples were collected from the middle third of the stem. Cross sections were prepared using a table microtome (LPC, Rolemberg \& Bohering, Retail and Import Ltda., Belo Horizonte, Brazil) and stained with phloroglucinol (JOHANSEN, 1940) to show lignin contents and dichromate (GABE, 1968), demonstrating the presence of phenolic compounds. Observations and imaging were performed using a photomicroscope (AX70TRF, Olympus Optical, Tokyo, Japan) equipped with a U-Photo camera system. Morphogenic capacities of the plants were evaluated using number of shoots (longer than $2 \mathrm{~mm}$ ) per explant, number of calli per explant, average regeneration frequency, fresh weight and dry weight.

The experiments were performed in a completely randomized design consisting of 3 treatments (flasks with one, two and no membrane) and 15 replications in the germination stage and in a 
factorial scheme $5 \times 2$ (flask sealing $x$ explants source) in the regeneration stage, with 10 replications. Data were transformed $(\arcsin \sqrt{x}$, for percentage data) when necessary and analyzed by analysis of variance followed by Tukey's test at $1 \%$ significance level for comparison of the means.

\section{RESULTS AND DISCUSSION}

The present study showed a significant effect on gas exchange levels for the following morphogenetic characteristics: percentage of germination, fresh weight, dry weight, hypocotyl length, leaf length, leaf width, number of leaves per plant, chlorophyll $a$, chlorophyll $b$, and carotenoids. Differences between one- and two- membrane flasks on germination, dry weight, hypocotyl length, leaf length, leaf width, and number of leaves per plant were non-significant, and the means were higher in those flasks than in the flasks without membranes (Table 1).

The decrease of leaf chlorophyll content in in vitro grown plants can limit the photosynthetic rate by reducing light absorption (CHRISTENSEN et al., 2008). In this study, for fresh weight, chlorophyll $a$, chlorophyll $b$, and carotenoids, the flasks with two membranes were superior to the others; although the treatment with one membrane was more efficient in increasing these characteristics than the treatment without membrane (Table 1).

The phloroglucinol test showed decreased plantlet vascular tissue lignin contents (xylem) from plants grown in flasks without membranes compared to those grown in flasks with 1 and 2 membranes (Figures 1A, 1B, and 1C). This behavior was also observed by RICHET et al. (2012), where under elevated $\mathrm{CO}_{2}$ carbon supply poplars showed increased lignin content, what evidences that Capsicum plants require higher gas exchange rates for optimum synthesis of lignin. In culture flasks with limited gas exchange, there is an increase in the humidity inside and limitation of $\mathrm{CO}_{2}$ concentration during photoperiod, which contributes to reduced differentiation of vascular tissue in in vitro propagated plants (MOHAMED \& ALSADON, 2010).

In the dichromate test, two-membranetreatment plants showed larger and more intense reddish-brown color reactions, characteristic of phenolic compounds, than flasks with 1 membrane or no membrane (Figures 1D, 1E, and 1F). JAAFAR et al. (2012) also reported that the enrichment of $\mathrm{CO}_{2}$ lead to increased expression of phenolic compounds in Labisia pumila. These results demonstrated a correlation between phenolics and morphogenesis characteristics, which were more developed in higher $\mathrm{CO}_{2}$ rates.

Increased gas exchange from the use of membranes directly influenced the development of morphogenesis in $\boldsymbol{C}$. annuum, promoting plant characteristics like rusticity and maturity highlighted by increased fresh and dry weight values. Similar results were reported in orchids of the genus Phalaenopsis cultivated in a higher $\mathrm{CO}_{2}$ concentration atmosphere, which showed increased biomass production (YOON et al., 2009).

Plantlets grown in flasks with membranes that increased gas exchange showed better anatomical characteristics, such as a better-developed vascular system and high concentration of phenolic compounds. Similar results were found in Capsicum chinense Jacq. plantlets grown in vessels that provided more gas exchange, which showed thicker epidermal cells and thicker and more differentiated vascular tissues (SANTANA-BUZZY et al., 2005).

Table 1 - Means of characteristics observed in Capsicum annuum plantlets, 30 days after germination.

\begin{tabular}{|c|c|c|c|c|c|}
\hline Sealing Type & GRM & FW & DW & $\mathrm{NL} / \mathrm{P}$ & $\mathrm{HL}$ \\
\hline Without membrane & $45.33 \mathrm{~b}^{*}$ & $8.06 \mathrm{c}$ & $0.56 \mathrm{~b}$ & $2.12 \mathrm{~b}$ & $5.69 \mathrm{~b}$ \\
\hline One membrane & $77.33 \mathrm{a}$ & $13.60 \mathrm{~b}$ & $2.73 \mathrm{a}$ & $3.63 \mathrm{a}$ & $10.47 \mathrm{a}$ \\
\hline Two membranes & $77.33 \mathrm{a}$ & $15.91 \mathrm{a}$ & $3.83 \mathrm{a}$ & $4.63 \mathrm{a}$ & $10.42 \mathrm{a}$ \\
\hline Sealing Type & LL & LW & CLa & $\mathrm{CL} b$ & $\mathrm{TCa}$ \\
\hline Without membrane & $17.05 \mathrm{~b}$ & $9.21 \mathrm{~b}$ & $13.49 \mathrm{c}$ & $4.69 \mathrm{c}$ & $2.21 \mathrm{c}$ \\
\hline One membrane & $26.74 \mathrm{a}$ & $13.85 \mathrm{a}$ & $37.07 \mathrm{~b}$ & $11.14 \mathrm{~b}$ & $5.32 \mathrm{~b}$ \\
\hline Two membranes & $25.25 \mathrm{a}$ & $12.83 \mathrm{a}$ & $47.15 \mathrm{a}$ & $15.57 \mathrm{a}$ & $7.71 \mathrm{a}$ \\
\hline
\end{tabular}

*Means indicated by the same letters are not significantly different as assessed by the Tukey test at $1 \%$ probability level. GRM $=$ germination $(\%) ; \mathrm{FW}=$ fresh weight $(\mathrm{g}) ; \mathrm{DW}=$ dry weight $(\mathrm{g}) ; \mathrm{NL} / \mathrm{P}=$ number of leaves per plantlet; HL = hypocotyl length $(\mathrm{cm}) ; \mathrm{LL}=$ leaf length $(\mathrm{mm}) ; \mathrm{LW}=$ leaf width $(\mathrm{mm}) ; \mathrm{CL} a=$ clorophyll $a\left(\mu \mathrm{g} \mathrm{cm}^{-2}\right) ; \mathrm{CL} b=$ clorophyll $b\left(\mu \mathrm{g} \mathrm{cm}^{-2}\right) ; \mathrm{TCa}=$ total carotenoids $\left(\mu \mathrm{g} \mathrm{cm}{ }^{-2}\right)$. 


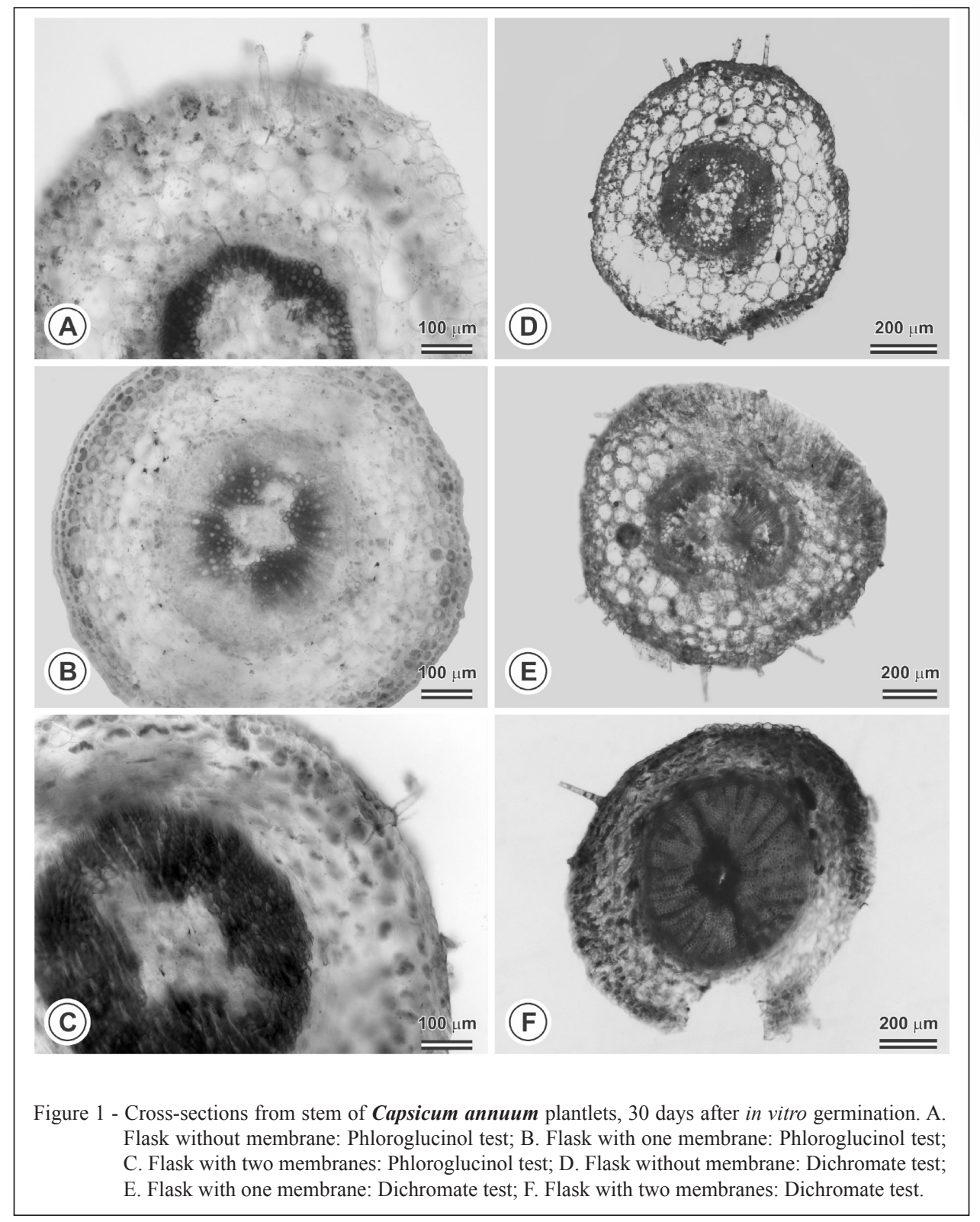

Higher gas exchange can increase the quality of plants grown in vitro as well as positively influence various tissue culture systems, such as roots, undifferentiated calli, and suspension cultures. RODRIGUES et al. (2011) evaluating the effect of gas exchange on the in vitro propagation of neem (Azadirachta indica), suggested that the use of membranes that allow higher gas exchange can improve shoot quality, reducing the occurrence of chlorosis and leaf senescence. Similarly, we observed that plantlets of $\boldsymbol{C}$. annuum cultured under higher gas exchange conditions showed less occurrence of leaf abscission, senescence, hyperhydricity, and chlorosis.
A positive effect of increased airflow on C. annuum shoot induction was observed, which is similar to results obtained by MOHAMED \& ALSADON (2011) with the same species. The authors reported that increased gas exchange in culture flasks resulted in better-developed shoots.

During the regeneration stage, both explant type and gas exchange levels were statistically different, but their interaction was not. Hypocotyl segments showed higher fresh and dry weights and formed calli and shoots more effectively than cotyledon segments (Table 2). Plantlets cultured in 2-membrane flasks induced the highest number of shoots (de novo shoot 
Table 2 - Influence of flask sealing and explant source on Capsicum annuum morphogenesis.

\begin{tabular}{|c|c|c|c|c|c|}
\hline \multicolumn{2}{|l|}{ Explant } & $\mathrm{NC} / \mathrm{E}$ & $\mathrm{ARF}$ & FW & DW \\
\hline \multicolumn{2}{|l|}{ Hypocotyl } & $0.81667 \mathrm{a}^{*}$ & $56 \mathrm{a}$ & $1.3 \mathrm{a}$ & $0.217 \mathrm{a}$ \\
\hline \multicolumn{2}{|l|}{ Cotyledon } & $0.31667 \mathrm{~b}$ & $39 \mathrm{~b}$ & $0.6 \mathrm{~b}$ & $0.057 \mathrm{~b}$ \\
\hline \multicolumn{6}{|c|}{ 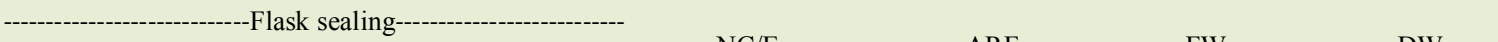 } \\
\hline Germination & Regeneration & $\mathrm{NC} / \mathrm{E}$ & ARF & FW & DW \\
\hline No membrane & No membrane & $0.625 \mathrm{~b}$ & $26 \mathrm{c}$ & $1.300 \mathrm{a}$ & $0.159 \mathrm{a}$ \\
\hline No membrane & Two membranes & $0.367 \mathrm{c}$ & $76 \mathrm{a}$ & $0.667 \mathrm{~b}$ & $0.078 \mathrm{~b}$ \\
\hline One membrane & One membrane & $0.600 \mathrm{~b}$ & $53 \mathrm{~b}$ & $0.925 \mathrm{ab}$ & $0.088 \mathrm{ab}$ \\
\hline Two membranes & No membrane & $0.933 \mathrm{a}$ & $33 \mathrm{c}$ & $1.192 \mathrm{a}$ & $0.120 \mathrm{a}$ \\
\hline Two membranes & Two membranes & $0.575 \mathrm{~b}$ & $87 \mathrm{a}$ & $0.625 \mathrm{~b}$ & $0.049 \mathrm{~b}$ \\
\hline
\end{tabular}

*Means indicated by the same letters are not significantly different as assessed by the Tukey test at $1 \%$ probability level. NC/E $=$ number of callus per explant; $\mathrm{ARF}=$ average regeneration frequency $(\%) ; \mathrm{FW}=$ fresh weight $(\mathrm{g})$; DW $=$ dry weight $(\mathrm{g})$. (Black arrows indicate the cultivation sequence).

organogenesis), regardless of gas exchange levels in the germination stage, those grown in flasks with 1 membrane showed intermediary regeneration shoot frequency during germination and regeneration stages and plantlets cultivated in flasks without membranes during regeneration stages showed less regeneration (Table 2).

The highest means of fresh and dry weights were obtained in plants grown in flasks without membranes in the regeneration phase, and the lowest means occurred in plants grown in flasks with 2 membranes in the regeneration phase; sealing type used in the germination stage in both treatments showed no influence. Flasks with 1 membrane showed intermediate values throughout the entire cultivation, similar to values shown in the other treatments (Table 2). PIÑERO et al. (2014) suggested that the application of high $\mathrm{CO}_{2}$ altered the hormonal balance, resulting in significant changes at the growth in Capsicum annuum.

An inverse relationship was reported between callus development and gas exchange. Callus formation was also influenced by explant source, and hypocotyl segments were more efficient than cotyledon segments. These results are contradictory to those reported by ZOBAYED et al. (1999), who reported a positive correlation between these two characteristics.

\section{CONCLUSION}

The authors concluded that sealing type influenced the morphogenic responses of Capsicum annuum, suggesting that an increase in gas exchange has a positive effect on biomass production and acclimatization of the plantlets. However, the cultivation of explants in flasks with lower gas exchange was more effective in callus induction than regeneration, and hypocotyls were more effective than cotyledons in morphogenesis induction.

\section{ACKNOWLEDGMENTS}

The authors thank the Brazilian sponsoring agencies Conselho Nacional de Desenvolvimento Científico e Tecnológico $(\mathrm{CNPq})$, Fundação de Amparo à Pesquisa do Estado de Minas Gerais (FAPEMIG), and Coordenação de Aperfeiçoamento de Pessoal de Ensino Superior (CAPES) for financial support.

\section{REFERENCES}

ARAGÓN, C. et al. Ex vitro acclimatization of plantain plantlets micropropagated in temporary immersion bioreactor. Biologia Plantarum, v.54, p.237-244, 2010. Available from: <http://link. springer.com/article/10.1007\%2Fs10535-010-0042-y>. Accessed: Ago. 11, 2014.

CHA-UM, S. et al. Effects of temperature and relative humidity during in vitro acclimatization, on physiological changes and growth characters of Phalaenopsis adapted to in vivo. Australian Journal of Crop Science, v.4, p.750-756. 2010. Available from: $<\mathrm{http} / /$ www.highbeam. com/doc/1P3-2268154461.html>. Accessed: Ago. 11, 2014.

CORRÊA, J.P.O. et al. In vitro photoautotrophic potential and ex vitro photosynthetic competence of Pfaffia glomerata (Spreng.) Pedersen accessions. Plant Cell, Tissue and Organ Culture, v.121, p.289-300, 2015. Available from: http://link.springer.com/ article/10.1007/s11240-014-0700-4. Accessed: Sept. 20, 2015. doi: 10.1007/s11240-014-0700-4.

CHRISTENSEN, B. et al. In vitro culture of Hibiscus rosasinensis L.: Influence of iron, calcium and BAP on establishment and multiplication. Plant Cell, Tissue and Organ Culture, v.93, p.151-161, 2008. Available from: <http://link.springer.com/artic le/10.1007\%2Fs11240-008-9354-4>;. Accessed: Sept. 12, 2015. doi: $10.1007 / \mathrm{s} 11240-008-9354-4$.

GABE, M. Techniques histologiques. Paris: Masson \& Cie, 1985. 1113p.

HAZARIKA, B.N. Morpho-physiological disorders in in vitro culture of plants. Scientia Horticulturae, v.108, p.105-120, 2006. Available from: $<$ http://dx.doi.org/10.1016/j.scienta.2006.01.038>. Accessed: Ago. 11, 2014. doi: 10.1016/j.scienta.2006.01.038.

GARRUÑA-HERNÁNDEZ, R. et al. Enrichment of carbon dioxide in the atmosphere increases the capsaicinoids content in 
Habanero peppers (Capsicum chinense Jacq.). Journal of the Science of Food and Agriculture, v.93, p.1385-1388, 2013. Available from: <http://onlinelibrary.wiley.com/doi/10.1002/ jsfa.5904/epdf>. Accessed: Sept. 18, 2015. doi: 10.1002/jsfa.5904.

IAREMA, L. et al. Photoautotrophic propagation of Brazilian ginseng [Pfaffia glomerata (Spreng.) Pedersen]. Plant Cell, Tissue and Organ Culture, v.110, p.227-238, 2012. Available from: <http://link.springer.com/article/10.1007/s11240-012-01456>. Accessed: Sept. 12, 2015. doi: 10.1007/s11240-012-0145-6.

JAAFAR, H.Z.E. et al. Phenolics and flavonoids compounds, phenylanine ammonia lyase and antioxidant activity responses to elevated $\mathrm{CO}_{2}$ in Labisia pumila (Myrisinaceae). Molecules, v.17, p.6331-6347, 2012. doi: 10.3390/molecules17066331.

JOHANSEN, D.A. Plant microtechnique. New York: McGrawHill Book, 1940. 523p.

KOTHARI, S.L. et al. Chilli peppers - A review on tissue culture and transgenesis. Biotechnology Advances, v.28, p.35-48, 2010. Available from: <http://www.ncbi.nlm.nih.gov/ pubmed/19744550>. Accessed: Ago. 11, 2014. doi: 10.1016/j. biotechadv.2009.08.005.

KOZAI, T. Photoautotrophic micropropagation - Environmental control for promoting photosynthesis. Propagation of Ornamental Plants, v.10, p.188-204, 2010. Available from: <http://www.ipps. org/Papers/WesternNA/kubota.pdf >. Accessed: Ago. 11, 2014.

MOHAMED, M.A.H.; ALSADON, A.A. Influence of ventilation and sucrose on growth and leaf anatomy of micropropagated potato plantlets. Scientia Horticulturae, v.123, p.295-300, 2010. Available from: $<$ http:// www.sciencedirect.com/science/article/pii/S0304423809004488>. Accessed: Sept. 12, 2015. doi: 10.1016/j.scienta.2009.09.014.

MOHAMED, M.A.H.; ALSADON, A.A. Effect of vessel type and growth regulators on micropropagation of Capsicum annuum. Biologia Plantarum, v.55, p.370-374, 2011. Available from: $<$ http://link.springer.com/article/10.1007\%2Fs10535-011-0057-z>. Accessed: Ago. 11, 2014. doi: 10.1007/s10535-011-0057-z.

MURASHIGE, T.; SKOOG, F. A revised medium for rapid growth and biossays with tobacco tissue cultures. Physiologia Plantarum, v.15, p.473-497, 1962.

PIÑERO, M.C. et al. Regulation of hormonal responses of sweet pepper as affected by salinity and elevated $\mathrm{CO}_{2}$ concentration. Physiologia Plantarum, v.151, p.375-389, 2014. Available from: $<$ http://onlinelibrary.wiley.com/doi/10.1111/ppl.12119/epdf $>$. Accessed: Sep. 4, 2014. doi: 10.1111/ppl.12119.

RICHET, N. et al. Elevated $\mathrm{CO}_{2}$ and/or modify lignifications in the wood of poplars (Populous tremula $x$ alba). Journal of Experimental Botany, v.11 p.4291-4301, 2012. Available from: $<$ https://www.ncbi.nlm.nih.gov/pmc/articles/PMC3398455/pdf/ ers118.pdf>. Accessed: Jul. 28, 2014. doi: 10.1093/jxb/ers118.

RODRIGUES, M. et al. Effects of flask sealing and growth regulators on in vitro propagation of neem (Azadirachta indica A. Juss.). In Vitro Cellular \& Developmental Biology-Plant, v.48, p.67-72, 2011. Available from: <http://link.springer.com/article/1 0.1007\%2Fs11627-011-9398-8>. Accessed: Ago. 11, 2014. doi: 10.1007/s11627-011-9398-8.
SALDANHA, C.W. et al. $\mathrm{A} \mathrm{CO}_{2}$-enriched atmosphere improves in vitro growth of Brazilian ginseng [Pfaffia glomerata (Spreng.) Pedersen]. In Vitro Cellular \& Developmental Biology Plant, v.49, p.433-444, 2013. Available from: <http://link.springer.com/ article/10.1007\%2Fs11627-013-9529-5>. Accessed: Sept. 11, 2015. doi: 10.1007/s11627-013-9529-5.

SALDANHA, C.W. et al. $\mathrm{CO}_{2}$-enriched atmosphere and supporting material impact the growth, morphophysiology and ultrastructure of in vitro Brazilian-ginseng [Pfaffia glomerata (Spreng.) Pedersen] plantlets. Plant Cell, Tissue and Organ Culture, v.118, p.87-99, 2014. Available from: <http://link.springer.com/article/10.1007/s11240-0140464-x>. Accessed: Sept. 12, 2015. doi: 10.1007/s11240-014-0464-x.

SANTANA-BUZZY, N. et al. Regeneration of Habanero pepper (Capsicum chinense Jacq.) via organogenesis. Horticultural Science, v.40, p.1829-1831, 2005. Available from: <http://hortsci.ashspublications. org/content/40/6/1829.full.pdf>. Accessed: Ago. 11, 2014.

SANTOS, R.P. et al. Protocolo para extração de pigmentos foliares em porta-enxertos de videira micropropagados. Revista Ceres, v.55, p.356-364, 2008. Available from: <http://www.redalyc.org/ articulo.oa?id=305226703014>. Accessed: Ago. 11, 2014.

SHA VALLI KHAN, P.S. et al. Growth and net photosynthetic rates of Eucalyptus tereticornis Smith under photomixotrophic and various photoautotrophic micropropagation conditions. Plant Cell, Tissue and Organ Culture, v.71, p.141-146, 2002. Available from: <http://link.springer.com/article/10.102 3\%2FA\%3A1019935208418>. Accessed: Ago. 11, 2014 doi: 10.1023/A:1019935208418.

WELLBURN, A.R. The spectral determination of chlorophylls $a$ and $b$, as well as total carotenoids, using various solvents with spectrophotometers of different resolution. Journal of Plant Physiology, v.144, p.307-313, 1994. Available from: <http:// www.sciencedirect.com/science/article/pii/S0176161711811922>. Accessed: Ago. 11, 2014. doi: 10.1016/S0176-1617(11)81192-2.

YOON, Y.J. et al. Impact of in vitro $\mathrm{CO}_{2}$ enrichment and sugar deprivation on acclimatory responses of Phalaenopsis plantlets to ex vitro conditions. Environmental and Experimental Botany, v.65, p.183-188, 2009. Available from: < http://www.sciencedirect. com/science/article/pii/S0098847208000932>. Accessed: Jun. 19, 2014. doi: 10.1016/j.envexpbot.2008.08.001.

XIAO, Y. et al. Development and application of photoautotrophic micropropagation plant system. Plant Cell, Tissue and Organ Culture, v.105, p.149-158, 2011. Available from: <http://link. springer.com/article/10.1007\%2Fs11240-010-9863-9>. Accessed: Ago. 11, 2014. doi: 10.1007/s11240-010-9863-9.

ZOBAYED, S.M.A. et al. Evaluation of closed system, diffusive and humidity-induced convective through flow ventilation on the growth and physiology of cauliflower in vitro. Plant Cell, Tissue and Organ Culture, v.59, p.113-123, 1999. Available from: <http:// link.springer.com/article/10.1023\%2FA\%3A1006481506904>. Accessed: Ago. 11, 2014. doi: 10.1023/A:1006481506904.

ZOBAYED, S.M.A. et al. $\mathrm{NaCl}$ enhances growth and morphogenesis potential of Alhagi graecorum. In Vitro Cellular \& Developmental Biology-Plant, v.42, p.607-613, 2006. Available from: <http://link.springer.com/article/10.1079\%2FIVP2006811>. Accessed: Ago. 11, 2014. doi: 10.1079/IVP2006811. 